\title{
In-vitro fertilization in the mouse and the relevance of different sperm/egg concentrations and volumes
}

\author{
A. K. S. Siddiquey and J. Cohen* \\ Department of Obstetrics and Gynaecology, Birmingham Maternity Hospital, Edgbaston B15 2 TG \\ and ${ }^{*}$ Department of Zoology and Comparative Physiology, Birmingham University, P.O. Box 363, \\ Birmingham B15 2TT, U.K.
}

\begin{abstract}
Summary. The sperm:egg ratio and sperm concentration were varied separately by using different volumes (1-100 $\mu$ ) and egg numbers (1-15). The \% fertilization was determined by sperm concentration in large volumes $(10-100 \mu \mathrm{l})$. In small volumes $(1$ or $5 \mu \mathrm{l}$ ) the number of spermatozoa/egg determined penetration rate; the effective epididymal sperm number/fertilization was 250-350. Spermatozoa obtained from the oviducts (i.e. naturally selected) gave good fertilization responses and low concentrations of epididymal spermatozoa were also more effective when oviducal fluid and cumulus cells were included in the inseminating volume. We conclude that sperm/egg collision rate is the most important factor determining \% fertilization, although heterogeneity of epididymal spermatozoa limits fertilization rate at low sperm: egg ratios.
\end{abstract}

\section{Introduction}

All morphologically normal, motile spermatozoa in an ejaculate are usually considered to be physiologically capable of fertilization; in clinical practice semen samples are usually graded for number, morphology and motility. Cohen $(1973,1975)$ suggested that spermatozoa may be of two kinds, only one of which is normally permitted to reach the fertilization site at the time of fertilization, by selection in the female tract. He has been misquoted (Wallace, 1974; Gwatkin, 1977) as asserting that only a small proportion of spermatozoa can fertilize; the problem of whether each spermatozoon can fertilize if it gets to an egg remains to be solved.

Successful in-vitro fertilization in the mouse has been reported by many investigators using epididymal spermatozoa in various concentrations; 10-20 $\times 10^{5} / \mathrm{ml}$ (Miyamoto \& Chang, 1972), 15-30 × 105/ml (Kaufman, 1973) and 20-60 × 105/ml (Pavlok \& McLaren, 1972). In all these cases the number of spermatozoa used in the fertilizing drops was high, and any selection of (possibly heterogeneous) spermatozoa was arbitrary. In vivo, spermatozoa usually outnumber eggs, but not to a comparable extent (Braden \& Austin, 1954; Yanagimachi \& Mahi, 1976). In contrast, Bavister (1979) argued from his hamster in-vitro results (with sperm:egg ratios close to unity and using a "sperm motility factor" from the adrenal gland) that the majority of the spermatozoa contained in the hamster cauda epididymidis are potentially capable of fertilizing eggs.

Fraser \& Drury (1975) examined the importance of different sperm concentrations 
$\left(0.3-90 \times 10^{5} / \mathrm{ml}\right)$ and achieved acceptable rates of fertilization $(\sim 50 \%)$ with a concentration of $0.3 \times 10^{5} / \mathrm{ml}$, giving a mean sperm : egg ratio of $417: 1$ (spermatozoa/ fertilization $\sim 800: 1$ ). The volume of sperm suspension they used for each sample was $0.5 \mathrm{ml}$, with high concentrations of albumin $(32 \mathrm{mg} / \mathrm{ml})$ in the medium. The eggs, with cumulus mass and oviducal fluid, were placed directly in the inseminating medium.

So far as we are aware there has been no distinction between concentration and ratio, e.g. by varying the volumes of the inseminating drops. We therefore investigated similar concentrations of spermatozoa in different volumes and with different numbers of eggs in each kind of inseminating drop. We also examined the effect of cumulus mass and oviducal fluid in medium containing low sperm concentrations, and the fertilizing ability in vitro of very low numbers of presumably naturally selected (and so more homogeneous) oviducal spermatozoa.

\section{Materials and Methods}

Spermatozoa. Modified Tyrode's solution (Whittingham, 1971) was made up, but with 1.54 $\mu$ M-pyruvate and $8 \mathrm{mg}$ crystallized bovine serum albumin/ml (BSA: Sigma, London, U.K.) for all experiments. The basic sperm suspension was prepared by squeezing one blood-free cauda epididymidis and vas deferens from each of two F1 hybrid male mice, 2-4 months of age, into a $35 \times 10 \mathrm{~mm}$ Petri dish, containing $1 \mathrm{ml}$ medium under paraffin oil (BDH, Dorset, U.K.), equilibrated previously with $5 \% \mathrm{CO}_{2}$ in air. The dish (Falcon Plastics, Becton Dickinson \& Co., U.S.A.) was then placed over a warm plate $\left(30^{\circ} \mathrm{C}\right)$ and covered with a transparent plastic lid connected to a $5 \% \mathrm{CO}_{2}$ in air supply, and the colour of the medium was monitored to confirm the maintenance of $\mathrm{pH}$ between 7.2 and 7.4. After about $20 \mathrm{~min}$, from a well dispersed concentrated sperm suspension a dilution of $\times 10$ usually produced mostly motile spermatozoa at a concentration of $15-20 \times 10^{5} / \mathrm{ml}$. Sperm counts were later made in 3 dried, stained $20 \mu \mathrm{l}$ samples from this diluted sperm suspension for each part of each experiment; after one further dilution $(\times 1000), 50-300$ spermatozoa were usually present in each counting drop. Further dilutions of the basic sperm suspensions were made by adding medium, and final concentrations in each sample were calculated after counts of the slides. Careful motility estimates were made ( $\times 40$ phase contrast microscopy, mean of $\geqslant 4$ fields, subjective scoring by the same observer) after each dilution and after capacitation. Samples with $<70 \%$ progressive forward motility would have been discarded, but there were none. Dishes with drops of sperm suspension were then put in an anaerobic jar, gassed with $5 \% \mathrm{CO}_{2}$ in air, and kept at $37^{\circ} \mathrm{C}$ for $1 \mathrm{~h}$ for epididymal sperm capacitation.

Mice were treated with 4 i.u. PMSG and 4 i.u. hCG (48 $\mathrm{h}$ interval) and allowed to mate naturally $6 \mathrm{~h}$ later. At $3 \mathrm{~h}$ after mating the oviducts were flushed with a micrometer syringe and a fine bore needle ( 30 gauge) under a dissecting microscope, and the oviducal spermatozoa in the medium were collected in a Falcon dish and covered immediately with warm paraffin oil. These spermatozoa, unlike epididymal samples, were not further capacitated.

Eggs. F1 hybrid mice (Birmingham strains of C57, XT, x strong A, VG), 8-16 weeks of age were treated with 8 i.u. PMSG (Folligon: Intervet Lab. Ltd) and 8 i.u. hCG (Sigma), given intraperitoneally with an interval of 48-50 h. The animals were killed 12-13 h after the hCG injection and eggs were collected by tearing the distended ampulla in Tyrode's medium at room temperature $\left(23-25^{\circ} \mathrm{C}\right)$. Enzymic treatment with $0.1 \%$ hyaluronidase (Sigma, Type 1-S) in the medium removed cumulus and corona cells $(15-20 \mathrm{~min})$, and the eggs were then washed twice in fresh medium, before insertion into insemination drops $(1,5$ or 15 eggs with about $0.001-0.005$ $\mu \mathrm{l}$ medium). Eggs with cumulus cells, and oviducal fluid $(<1 \mu \mathrm{l})$ were directly released into the sperm suspension $(100 \mu \mathrm{l})$ by tearing the wall of the ampulla.

Fertilization. The dishes containing insemination drops under oil were incubated at $37^{\circ} \mathrm{C}$ in an anaerobic jar with $5 \% \mathrm{CO}_{2}$ in air atmosphere. To get an optimum assessment of penetration, 
$5 \mathrm{~h}$ were allowed. The eggs were then removed, washed in fresh medium and fixed overnight in $10 \%$ neutral formalin with $0.25 \%$ glutaraldehyde (to fix zonae). They were then stained with $0.5 \%$ lacmoid in acetic acid and examined by phase-contrast microscopy for pronuclei and fertilizing sperm tails.

\section{Results}

The results are given in Table 1.

Experiment $A$. Two concentrations of spermatozoa $\left(\sim 6 \times 10^{5} / \mathrm{ml}\right.$ and $\left.1.2 \times 10^{5} / \mathrm{ml}\right)$ in volumes of 5,20 or $100 \mu \mathrm{l}$ were used and the spermatozoa were capacitated in the two concentrations, i.e. after dilution. There were 1,5 or $15 \mathrm{eggs} /$ drop for insemination.

More than $75 \%$ of the eggs were fertilized in each of 5 repeat experiments, when insemination volumes of 100 and $20 \mu \mathrm{l}$ were used with a sperm concentration of $\sim 6 \times 10^{5} / \mathrm{ml}$.

Table 1. In-vitro fertilization of mouse gametes tested under different conditions

\begin{tabular}{|c|c|c|c|c|c|c|c|c|}
\hline \multirow[b]{2}{*}{ Exp. } & \multirow[b]{2}{*}{$\begin{array}{l}\text { No. of } \\
\text { replicates }\end{array}$} & \multirow{2}{*}{$\begin{array}{c}\text { Insemination } \\
\text { drop } \\
\text { vol. }(\mu)\end{array}$} & \multirow[b]{2}{*}{$\begin{array}{l}\text { Sperm } \\
\text { conc./ml }\end{array}$} & \multirow{2}{*}{$\begin{array}{l}\text { Total no. of } \\
\text { spermatozoa } \\
\text { in drop } \\
\times 1000\end{array}$} & \multirow[b]{2}{*}{$\begin{array}{l}\text { No. of eggs } \\
\text { in the drop }\end{array}$} & \multicolumn{2}{|c|}{ Fertilization } & \multirow{2}{*}{$\begin{array}{l}\text { No. of } \\
\text { spermatozoa/ } \\
\text { fertilized egg } \\
\times 1000\end{array}$} \\
\hline & & & & & & $\begin{array}{l}\text { No. of } \\
\text { eggs/total }\end{array}$ & $\begin{array}{c}\text { Mean \% } \\
\pm \text { s.d. }\end{array}$ & \\
\hline \multirow[t]{6}{*}{ A } & 5 & 100 & $6 \times 10^{5}$ & 60 & $\begin{array}{l}1(\times 5) \\
5 \\
15\end{array}$ & $\begin{array}{l}25 / 25 \\
23 / 25 \\
60 / 75\end{array}$ & $\begin{array}{c}100 \\
90 \pm 10 \\
80 \pm 10\end{array}$ & $\begin{array}{r}60 \\
13 \\
5\end{array}$ \\
\hline & 5 & 20 & $6 \times 10^{5}$ & 12 & $\begin{array}{l}1(\times 5) \\
5 \\
15\end{array}$ & $\begin{array}{l}23 / 25 \\
20 / 25 \\
59 / 75\end{array}$ & $\begin{array}{l}90 \pm 8 \\
80 \pm 16 \\
78 \pm 5\end{array}$ & $\begin{array}{l}13 \\
3 \\
1.05\end{array}$ \\
\hline & 3 & 5 & $6 \times 10^{5}$ & 3 & $\begin{array}{l}1(\times 5) \\
5 \\
15\end{array}$ & $\begin{array}{r}11 / 15 \\
7 / 15 \\
7 / 45\end{array}$ & $\begin{array}{l}73 \pm 9 \\
48 \pm 8 \\
15 \pm 11\end{array}$ & $\begin{array}{l}4 \\
1 \cdot 2 \\
1 \cdot 2\end{array}$ \\
\hline & 5 & 100 & $1.2 \times 10^{5}$ & 12 & $\begin{array}{l}1(\times 5) \\
5 \\
15\end{array}$ & $\begin{array}{r}16 / 25 \\
6 / 25 \\
15 / 75\end{array}$ & $\begin{array}{l}64 \pm 15 \\
23 \pm 15 \\
20 \pm 5\end{array}$ & $\begin{array}{l}18 \cdot 7 \\
10 \\
4\end{array}$ \\
\hline & 5 & 20 & $1.2 \times 10^{s}$ & $2 \cdot 4$ & $\begin{array}{l}1(\times 5) \\
5 \\
15\end{array}$ & $\begin{array}{r}13 / 25 \\
8 / 25 \\
10 / 75\end{array}$ & $\begin{array}{l}52 \pm 10 \\
32 \pm 10 \\
13 \pm 7\end{array}$ & $\begin{array}{l}4 \cdot 6 \\
1 \cdot 5 \\
1 \cdot 2\end{array}$ \\
\hline & 3 & 5 & $1.2 \times 10^{5}$ & 0.6 & $\begin{array}{l}1(\times 5) \\
5 \\
15\end{array}$ & $\begin{array}{l}2 / 15 \\
0 / 15 \\
0 / 45\end{array}$ & $\begin{array}{c}13 \pm 23 \\
0 \\
0\end{array}$ & $\begin{array}{l}4 \cdot 5 \\
0 \\
0\end{array}$ \\
\hline \multirow[t]{3}{*}{ B } & 2 & 10 & $10 \times 10^{5}$ & 10 & $\begin{array}{l}1(\times 5) \\
5 \\
15\end{array}$ & $\begin{array}{r}9 / 10 \\
9 / 10 \\
28 / 30\end{array}$ & $\begin{array}{l}90 \\
90 \\
93\end{array}$ & $\begin{array}{r}11 \cdot 1 \\
2 \cdot 2 \\
0 \cdot 7\end{array}$ \\
\hline & 2 & 5 & $10 \times 10^{5}$ & 5 & $\begin{array}{l}1(\times 5) \\
5 \\
15\end{array}$ & $\begin{array}{r}8 / 10 \\
9 / 10 \\
25 / 30\end{array}$ & $\begin{array}{l}80 \\
90 \\
84\end{array}$ & $\begin{array}{l}6 \cdot 2 \\
1 \cdot 2 \\
0 \cdot 4\end{array}$ \\
\hline & 2 & 1 & $10 \times 10^{5}$ & 1 & $\begin{array}{l}1(\times 5) \\
5 \\
15\end{array}$ & $\begin{array}{l}9 / 10 \\
8 / 10 \\
7 / 30\end{array}$ & $\begin{array}{l}90 \\
80 \\
23\end{array}$ & $\begin{array}{l}1 \cdot 1 \\
0 \cdot 25 \\
0.28\end{array}$ \\
\hline $\mathrm{C}$ & $\begin{array}{c}2 \\
(+ \text { cumulus }) \\
2 \text { (washed) }\end{array}$ & 100 & $\begin{array}{l}40 \times 10^{3} \\
40 \times 10^{3}\end{array}$ & 4 & 25 and 29 & $46 / 54$ & 85 & $0 \cdot 18$ \\
\hline $\mathrm{D}$ & 2 & 40 & $20 \times 10^{3}$ & 0.8 & 20 & $34 / 40$ & 85 & 0.05 \\
\hline $\mathrm{E}$ & $\begin{array}{c}\text { Dilution before } \\
1 \\
1\end{array}$ & $\begin{array}{c}\text { apacitation } \\
20 \\
100\end{array}$ & $\begin{array}{r}7 \times 10^{5} \\
1.4 \times 10^{5}\end{array}$ & $\begin{array}{l}14 \\
14\end{array}$ & $\begin{array}{l}15 \\
15\end{array}$ & $\begin{array}{r}14 / 15 \\
5 / 15\end{array}$ & $\begin{array}{l}93 \\
33\end{array}$ & $\begin{array}{l}1 \\
2 \cdot 8\end{array}$ \\
\hline & $\begin{array}{c}\text { Dilution after ca } \\
1 \\
1\end{array}$ & $\begin{array}{r}\text { acitation } \\
20 \\
100\end{array}$ & $\begin{array}{r}7 \times 10^{5} \\
1.4 \times 10^{5}\end{array}$ & $\begin{array}{l}14 \\
14\end{array}$ & $\begin{array}{l}15 \\
15\end{array}$ & $\begin{array}{r}12 / 15 \\
6 / 15\end{array}$ & $\begin{array}{l}80 \\
40\end{array}$ & $\begin{array}{l}1 \cdot 15 \\
2 \cdot 33\end{array}$ \\
\hline
\end{tabular}


When the volume was $5 \mu$ drops with the same sperm concentration the fertilization rates were high with 1 or 5 eggs but reduced when 15 eggs were used in each drop. For all volumes the fertilization percentage was reduced when a more dilute sperm suspension was used $\left(1.2 \times 10^{5} / \mathrm{ml}\right)($ Table 1$)$.

Experiment $B$. A single sperm concentration $\left(\sim 10 \times 10^{5} / \mathrm{ml}\right)$ in a volume of 1,5 or $10 \mu \mathrm{l}$ was used, and there were 1, 5 or 15 eggs in each volume. With the smaller drops, paraffin oil was equilibrated with a small volume of medium before its use to cover sperm suspensions, to prevent the possibility of loss of critical components from the tiny drops of medium.

Nearly all the eggs were fertilized in small droplets (10 or $5 \mu \mathrm{l})$ with a sperm concentration of $10 \times 10^{5} / \mathrm{ml}$. The $1 \mu \mathrm{l}$ sperm suspensions with 1 or 5 eggs gave a high fertilization rate but reduced numbers of eggs were fertilized when 15 were present, i.e. the same number of eggs were fertilized, although more were available. When 5 or 15 eggs were available there was a sperm ratio per fertilization of 250-350:1. (A pilot experiment, not reported here, showed poor penetration in $5 \mu \mathrm{l}$ and $1 \mu \mathrm{l}$ drops without equilibration, but the above results were with equilibrated drops.)

Experiment $C$. The inclusion of cumulus mass and oviducal fluid in the insemination drop $(100 \mu \mathrm{l})$ with a low number of epididymal spermatozoa $\left(40 \times 10^{3} / \mathrm{ml}\right)$ produced a better fertilization response than when the eggs were washed and cumulus free.

Experiment $D$. Naturally capacitated oviducal spermatozoa fertilized a large proportion of the eggs.

Experiment $E$. Spermatozoa were diluted before or after capacitation, to investigate whether capacitation in dilute medium gave results different from those of Exp. A. Spermatozoa capacitated before or after 5 -fold dilutions produced similar results.

\section{Discussion}

As in the results of other workers, (Fraser \& Drury, 1975; Wolf \& Inoue, 1976; Wolf, 1978) sperm concentration was the major determinant of fertilization rate. In larger volumes, we needed about 1000 spermatozoa/fertilization. Our $5 \mu$ drops in Exp. A, however, did less well (1200/fertilization). This was probably because of loss of ingredients from the medium to the paraffin oil. In Exp. B the drops were in equilibrated paraffin and gave much better results (400 spermatozoa/fertilization). It is also clear that $80-90 \%$ fertilization is the usual maximum possible, even with excess spermatozoa and 10-20\% of the eggs are probably not fertilizable. This means that sperm effectiveness cannot be estimated when more than about $75 \%$ eggs are fertilized - all that can be said is that sperm numbers were at least adequate.

The effect of 5-fold dilution of sperm suspension was quite evident. The same number of spermatozoa $\left(12 \times 10^{3}\right)$ when used in $100 \mu$ rather than $20 \mu$ volumes (with 15 eggs) gave $20 \%$ as compared with $80 \%$ fertilization. Probably there were only one-fifth of the collisions between spermatozoa and eggs in the larger volumes. The fertilizing efficiency, however, was low compared with that reported by Fraser \& Drury (1975) who obtained about $50 \%$ fertilization using $0.5 \mathrm{ml}$ inseminating volume with about $15 \times 10^{3}$ spermatozoa $\left(0.3 \times 10^{5} / \mathrm{ml}\right)$, but with an average egg number of 36 . The results obtained by Fraser \& Drury (1975) might be due to the high amount of albumin $(32 \mathrm{mg} / \mathrm{ml})$ in the medium, and particularly to the direct release of eggs from oviducts along with cumulus cells and oviducal fluid in the sperm suspension.

Suggestive evidence for a positive effect of cumulus cells in fertilization in the mouse also comes from the work of Cross \& Brinster (1970). Pavlok \& McLaren (1972) reported successful capacitation of mouse spermatozoa with oviducal fluid during fertilization in vitro. Bavister (1969) also regarded oviducal fluid as a suitable environment for the fertilization process in the hamster. These views are supported by the present results $(85 \%)$ when cumulus cells and oviducal fluid were used, with a very low sperm concentration $\left(40 \times 10^{3} / \mathrm{ml}\right)$. It is clear that 
in-vitro experiments involving the cumulus mass are not directly comparable with those using hyaluronidase-treated eggs. Nevertheless, from the consistency of our other results, cumulus-free eggs can be compared with each other.

The achievement of very high rates of fertilization in the smaller volumes, 10 and $5 \mu$, with sperm concentrations of $10 \times 10^{5} / \mathrm{ml}$ was no doubt due to the high probability of sperm-egg collisions. The low fertilization rate in the $5 \mu \mathrm{l}$ droplets with $15 \mathrm{eggs}$, and in the $1 \mu \mathrm{l}$ droplets with 5 or 15 eggs, showed the importance of the total number of spermatozoa available in the suspension. In the $1 \mu \mathrm{l}$ droplet, with about 1000 spermatozoa, there were apparently not sufficient effective gametes to fertilize even 5 of $15 \mathrm{eggs}$, although fertilization rates were good with 1 and 5 eggs: 250-350 spermatozoa per fertilization were needed even when they were in close proximity to the eggs.

About 800 naturally capacitated, and possibly highly selected, oviducal spermatozoa showed much higher efficacy, giving a sperm:egg ratio per fertilization of 50:1 even in a $40 \mu l$ drop.

The necessity for large numbers of epididymal spermatozoa per fertilization when using in-vitro methods, as shown by different workers (Niwa \& Chang, 1974; Tsunoda \& Chang, 1975; Fraser \& Drury, 1975), and the contrast between the in-vitro results with such epididymal spermatozoa and with oviducal (presumably selected) samples in this study, confirms our belief in the heterogeneity of epididymal spermatozoa. Oviducal spermatozoa appear to contain a higher proportion of fecund gametes. But this finding, that mouse epididymal spermatozoa, even when in close proximity to eggs, as in the $1 \mu \mathrm{l}$ droplets, cannot apparently achieve sperm:egg fertilization ratios close to unity cannot be related to normal in-vivo fertilization strategy. Only a few spermatozoa are actually tested at the eggs in vivo, there are not even hundreds at the site of fertilization. If this was simply reduction in number, fecundity would not differ in oviducal/epididymal samples. Because oviducal spermatozoa performed much better in our system, we suggest that the female concentrates fecund spermatozoa into the oviduct. The relation of this selection to temporal heterogeneity in ejaculated spermatozoa, or to the sperm redundancy theories of Cohen $(1973,1975)$, is difficult to assess and the successive arrivals of spermatozoa in the mouse ampulla are presently being tested for fecundity.

We thank Dr D. G. Whittingham for help in initiating a part of this work in his laboratory, and Dr A. McLaren for valuable suggestions. A.K.S.S. received a Research Training Award from the Commonwealth Scholarship Commission in U.K., No. Bangladesh M/10 1979.

\section{References}

Bavister, B.D. (1969) Environmental factors important for in vitro fertilization in the hamster. J. Reprod. Fert. 18, 544-545, Abstr.

Bavister, B.D. (1979) Fertilization of hamster eggs in vitro at sperm-egg ratios close to unity. J. exp. Zool. 210, 259-264.

Braden, A.W.H. \& Austin, C.R. (1954) Numbers of sperms about the eggs in mammals and its significance for normal fertilization. Aust. J. biol. Sci. 7, 543-551.

Cohen, J. (1973) Crossovers, sperm redundancy and their close association. Heredity 31, 408- 413.

Cohen, J. (1975) Gamete redundancy-wastage or selection? In Gamete Competition in Plants and Animals, pp. 99-112. Ed. D. L. Mulcahy. Elsevier, Amsterdam.
Cross, P.C. \& Brinster, R.L. (1970) In vitro development of mouse oocytes. Biol. Reprod. 3, 298-305.

Fraser, L.R. \& Drury, L.M. (1975) The relationship between sperm concentration and fertilization in vitro of mouse eggs. Biol. Reprod. 13, 513-518.

Gwatkin, R.B.L. (1977) Fertilization Mechanism in Man and Mammals, p. 41. Plenum Press, New York.

Kaufman, M. (1973) Timing of the first cleavage division of the mouse and the duration of its component stages: a study of living and fixed eggs. J. Cell Sci. 12, 799-808.

Miyamoto, H. \& Chang, M.C. (1972) Development of mouse eggs fertilized in vitro by epididymal spermatozoa. J. Reprod. Fert. 30, 135-137.

Niwa, K. \& Chang, M. (1974) Optimal sperm concentration and minimal number of spermatozoa for 
fertilization in vitro of rat eggs. J. Reprod. Fert. 40, 471-474.

Pavlok, A. \& McLaren, A. (1972) The rôle of cumulus cells and the zona pellucida in fertilization of mouse eggs in vitro. J. Reprod Fert. 29, 91-97.

Tsunoda, Y. \& Chang, M.C. (1975) Penetration of mouse eggs in vitro: optimal sperm concentration and minimal number of spermatozoa. J. Reprod. Fert. 44, 139-142.

Wallace, H. (1974) Chiasmata have no effect on fertility. Heredity 33, 423-429.
Whittingham, D. (1971) Culture of mouse ova. $J$. Reprod. Fert., Suppl. 14, 7-21.

Wolf, D.P. (1978) The block to sperm penetration in zona-free mouse eggs. Devl Biol. 64, 1-10.

Wolf, D.P. \& Inoue, M. (1976) Sperm concentration dependency in the fertilization and zonae sperm binding properties of mouse eggs inseminated in vitro. J. exp. Zool. 196, 27-38.

Yanagimachi, R. \& Mahi, C.A. (1976) The sperm acrosome reaction and fertilization in the guinea-pig: a study in vivo. J. Reprod. Fert. 46, 49-54.

Received 27 November 1981 